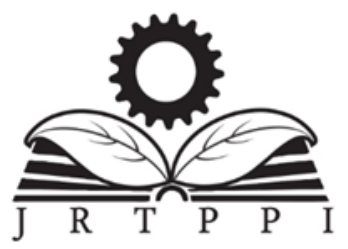

Vol. 10 No. 2 (2019) 29-35

Jurnal Riset

Teknologi Pencegahan Pencemaran Industri

Kementerian

Perindustrian

REPUBLIK INDONESIA

Journal homepage : jrtppi.id

\title{
Waste to Product : Bisolum-Bricks, Incorporating of WWTP Sludge of Textile Industry into Bricks for Wall Pairs
}

\author{
Armas Arifin Arbunowo ${ }^{1}$, Purwanto ${ }^{2}$, Mochamad Arief Budihardjo ${ }^{3}$ \\ ${ }^{1}$ Environmental Sciences Master Program Study, Postgraduate School, Universitas Diponegoro, Jl. Imam Bardjo, SH No.3-5 Semarang \\ ${ }^{2}$ Chemical Engineering Department, Faculty of Engineering, Universitas Diponegoro, Jl. Prof. Soedarto, Tembalang, Semarang \\ ${ }^{3}$ Department of Environmental Engineering, Faculty of Engineering, Universitas Diponegoro, Jl. Prof. Soedarto, Tembalang Semarang
}

A R T IC LE I N F O

\section{Article history:}

Received 26 September 2019

Received in revised form 5 December 2019

Accepted 5 December 2019

Available online 16 December 2019

\section{Keywords :}

Bisolum

Bricks

Textiles

WWTP Sludge

TCLP

LD-50

\section{A B S T R A C T}

The disposal of WWTP sludge is one of problems in textiles industry, which requires serious attention to find a way out. Utilization of sludge from the textile industry wastewater treatment, according to the Republic of Indonesia Goverment Regulation No.110 year 2014, can be used as a mixture of brick raw materials, must consider the availability of technology, meet environmental quality standards and meet technical requirements for use. Environmental feasibility refers to Goverment Regulation No.110 year 2014, carried out with TCLP toxicity tests on raw materials for soil, WWTP sludge and brick products. Acute toxicity test LD 50, carried out on brick products in which using a mixture of WWTP Sludge. Technical feasibility is carried out by testing the quality of brick products in accordance with solid brick Nasional Indonesian Standard (SNI) for wall pairs. Research results prove the toxicity test on raw materials and brick products with a mixture of up to $60 \%$ of waste, still meets the requirements of TCLP and LD.50 according to IGR No.110 year 2014. Test the quality of bricks at the use of $40 \%$ and $60 \%$ mixture of sludge still meet Nasional Indonesian Standard (SNI 15-2094-2000) solid red brick for wall pairs.

\section{INTRODUCTION}

The disposal of sludge from the wastewater treatment unit is one of the problems in the Dyeingfinishing textile industry, which needs serious attention from all parties, due to the nature of its characteristics which are considered to contain hazardous substances such as acids or alkalis substances and some hazardous metal such as chromium, which have the potential to cause environmental pollution, if not properly managed.

Balan \& Monteiro (2001), stated that the wastewater treatment process in the Wastewater Treatment Unit, produces a number of sludge from chemical treatment processes, and or sludge from biological treatment. The textile industry that treats wastewater at $50 \mathrm{~m}^{3}$ per hour can produce 1 to 10 tons of sludge per day.

According to Indonesia Government Regulation No. 101year 2014, the management of Toxic and Hazardous Waste Material is intended so that the Toxic and Hazardous Waste Material produced by each production unit is as little as possible and even attempted to zero, by striving to reduce the source by processing materials, substituting materials, regulating operational activities, and using them clean technology. If toxic and hazardous

\footnotetext{
*Correspondence author.

E-mail : armas.bbtppi@gmail.com
} 
material waste is still produced, the endeavored use of toxic and hazardous waste.

Utilization of WWTP sludge as a mixture of brick making has been done and has produced results that meet the technical feasibility and environmental feasibility, but this has not been able to encourage relevant parties to utilize this WWTP sludge, because understanding the concept of re-utilization of industrial WWTP sludge has only been raised since the issuance of the Indonesia Regulation Government No.110 of 2014. as an effort to solve problems in the textile industry, as well as efforts to reduce the impact environment due to exploitation of land use as raw material for bricks.

R. Baskar (2006) states that the use of sludge as a building and construction material not only converts waste into useful products but also minimizes the problem of sludge disposal WWTP and the reduction of exploitation of natural resources such as clay can also be prevented to avoid further environmental damage.

Jahagirdar (2013), stated another advantage of reusing sludge or sludge ash in burned clay bricks or tile is immobilization of heavy metals in the combustion process, organic matter is completely oxidized and removes all types of pathogens during the high temperature combustion process. Clay bricks with a combustion process, in general have been used as building materials with solid metric mainly because of its characteristics, such as good mechanical resistance, and satisfactory stability.

Utilization of various types of sludge waste for clay bricks mix shows various advantages in terms of physical and mechanical properties such as low density, lighter bricks, better compressive strength and even reduced energy consumption during combustion, although it also still shows some weaknesses. These studies have also shown that the use of sludge waste into a mixture of brick materials has a better impact on the environment.Chemical composition as well as heavy metals after combustion or solidification, on the final product according to standards Nasional Indonesian Standard (SNI 15-2094-2000)
.Utilization of sewage sludge can produce good quality bricks and provides environmentally friendly WWTP sludge disposal methods (Aeslina, 2014).

Toxic waste from the textile industry is solid waste in the form of sludge originating from the processing of liquid waste finishing and dyeing processes containing heavy metals (GR.No.101 / 2014).This study aims to find a solution of the problem of the textile industry's WWTP sludge.

\section{METHODS}

\subsection{Total metal test on WWTP Sludge and Soil as raw material}

Identification of potential metals contained in the WWTP sludge and soil raw material was carried out by total metal analysis with the reflux destruction method, according to the Standar Method for Examination Water and Wastewater APHA, 3111.B .(APHA,2017)

WWTP sludge used was taken from one of the textile industries with dyeing and finishing production processes. The process of treating the WWTP sludge has been carried out in factory with centrifuges dewatering, and continued by drying machine at temperatur $300^{\circ} \mathrm{C}$.

The samples is was homogeneous, weighed and determined its water content. Samples were added with 10 $\mathrm{mL} \mathrm{HNO}_{3} 1: 1$ refluxed at $95^{\circ} \mathrm{C}$ for 15 minutes. Cooling, add $10 \mathrm{~mL} \mathrm{H}_{2} \mathrm{O}_{2} 30 \%$, reflux, heat at $95^{\circ} \mathrm{C}$ for 2 hours. Cool and add mienral mineral free water to exactly $100 \mathrm{~mL}$. Filtered with Whatman 41, continued metal analysis with AAS. Calculate the metal content in the sampel.

\subsection{TCLP test on WWTP Sludge and Soil}

The extraction procedure in TCLP testing, refers to US.EPA, SW.846 Test Methode 1311, to determine the mobility of organic and inorganic analytes present in liquid, solid and multiphase wastes. Metal analysis using AAS, refers to the Standard Method for Examination of Water and Wastewater, APHA 3111.B

TCLP test was carried out by chrushing the material and shifting $9.5 \mathrm{~mm}$ in size. 5 gram of sample weigh dissolved in $96.5 \mathrm{~mL}$ of mineral free water. Take a $\mathrm{pH}$ measurement. If the $\mathrm{pH}$ is less then 5 , use a sodium 
acetate buffer with $\mathrm{pH}$ of 4.93 , but if the $\mathrm{pH}$ of solution more than 5, use acetic acid with a $\mathrm{pH}$ of 2.88. The measured $\mathrm{pH}$ in the solution was 4.9 so a sodium acetat buffer solution was used.

Furthermore, exctraction was carried out using a rotary agitator with of $30 \mathrm{rpm}$ for 18 hours. Next, the extracted soolution is filtered with a $0.6-0.8 \mu \mathrm{m}$ size glass fiber filter. Removed the solids.

The solution obtained from this filtering, acidic with nitric acid, $\mathrm{HNO}_{3}$, until the $\mathrm{pH}$ reaches 2. And then continued determination of metal by AAS.

\subsection{Testing of Toxicity Characteristics of brick product}

Test the characteristics of toxicity in brick products, carried out in 2 stages. The first step is TCLP testing using the procedure as in point 2 above. Then proceed with an acute oral toxicity test LD-50, using mice from Swiss strains aged 6-8 weeks, with an average weight of 27.6 grams. Acclimatization is carried out for 1 week, followed by testing for 14 days.

Referring to the Regulation of the Head of the Republic of Indonesia Drug and Food Supervisor Agency No.7 year 2014, the testing procedures is shown in the following figure 1 .

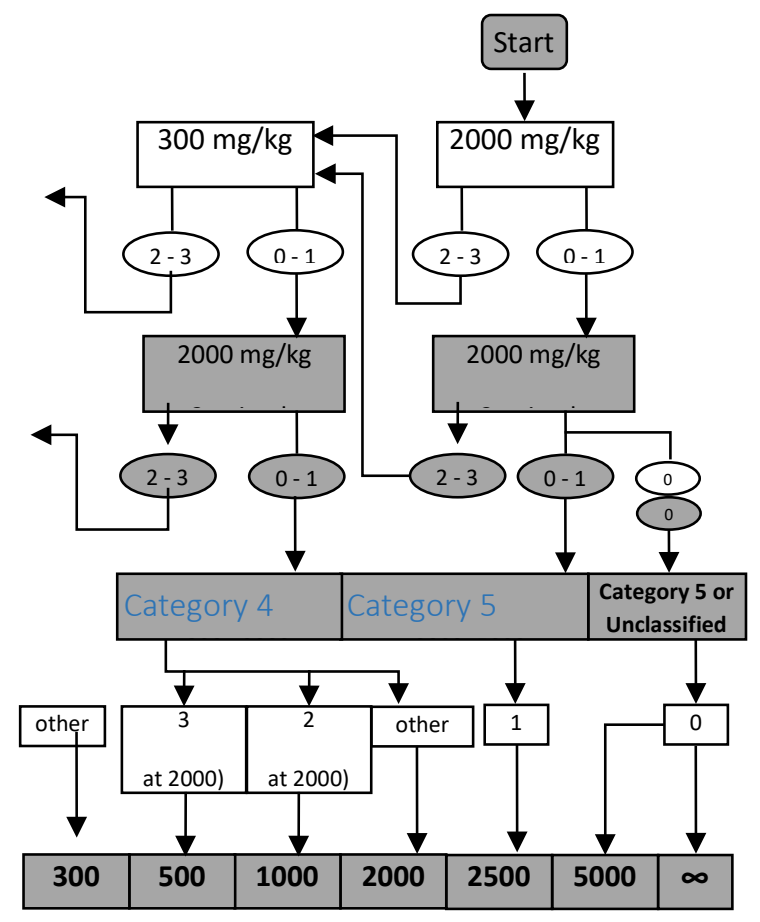

Figure 1. LD-50 Test Procedure

\subsection{Brick Quality Testing}

The bricks-making phase starts from mixing, curing, molding, drying and burning at the local brickmaking site, following the usual manufacturing method.

Testing on bricks is done by physical obsevation and laboratory testing. Physical observations include size (dimension), cracks (pores), and color after burning. Dry srinkage is done after the bricks are dried for 5 days and dried in the sun for 3 days.

Testing the quality of bricks in the laboratory, refers to the Indonesian National Standard for solid bricks for wall pairs, SNI -15-2094-2000, which includes testing of compressive strength and water absorption.

\section{RESULT AND DISCUSSION}

The resarch process begins with the sampling of wastewater treatment sludge that has been dried in the textile industry, and clay sampling at the brick making location.

The first step is to conduct a total metal test to determine the potential of the metal contained in the raw material. Metal test result on material are shown in Table.1.

Table 1: Total Metal Test Results on Raw Material

\begin{tabular}{lllc}
\hline \hline \multirow{2}{*}{ No } & \multicolumn{1}{c}{ Parameter } & \multicolumn{2}{c}{ Result $(\mathrm{mg} / \mathrm{Kg})$} \\
\cline { 3 - 4 } & & \multicolumn{1}{c}{ Soil } & Sludge \\
\hline 1 & Barium, Ba & 0.079 & $<0.003^{(*)}$ \\
2 & Boron, B & 80.01 & 38.04 \\
3 & Cadmium, Cd & $<0.005^{(*)}$ & 0.600 \\
4 & Chromium, Cr & 7.598 & 2.120 \\
5 & Copper, Cu & 9.597 & 63.75 \\
6 & Lead, Pb & $<0.030^{(*)}$ & 5.814 \\
7 & Mercury, Hg & 0.070 & 0.088 \\
8 & Selenium, Se & 0.034 & 0.127 \\
9 & Silver, Ag & $<0.030^{(*)}$ & 1.900 \\
10 & Zinc, Zn & 26.69 & 83.52 \\
\hline \hline
\end{tabular}


${ }^{(*)}$ Method detection limit

Test result in Table.1. shows that the metal contained in sludge and soil material, have the same tendency, in the sense that some metal such as Boron, Zink and Copper are quite dominant.

\subsection{Metal Leaching Test Result on Raw Material}

Based on TCLP Test Result in Table.2, it can be seen that some metals such as Boron, Chromium and
Copper, show the potential for leaching, but when compared with the requirements of Quality Standards, it still meets the maximum allowable content

This is supported by the fact that the result of TCLP analysis conducted in the dyeing-finishing textile industry which were tested in laboratories since 2011 year until 2018 year, are presented ini Table. 3

Base on the test result, it can be seen that the sludge processed by the textile industry is still safe to be used as a mixture of bricks.

Table 2: TCLP Test Results for Bricks Raw Material

\begin{tabular}{|c|c|c|c|c|c|c|c|}
\hline \multirow{2}{*}{ Parameter } & \multirow{2}{*}{ Unit } & \multicolumn{3}{|c|}{ Test Result } & \multicolumn{3}{|c|}{ Quality Hazardous Waste Standard } \\
\hline & & Soil & WWTP Sludg & Mixture & TCLP-A & TCLP-B & before Landfill \\
\hline Arsenic, As & $\mathrm{mg} / \mathrm{L}$ & $<0.003^{(*)}$ & $<0.003^{(*)}$ & $<0.003^{(*)}$ & 3 & 0.5 & 0.5 \\
\hline Silver, Ag & $\mathrm{mg} / \mathrm{L}$ & $<0.030^{(*)}$ & $<0.030^{(*)}$ & $<0.030^{(*)}$ & 40 & 5 & 5 \\
\hline Boron, B & $\mathrm{mg} / \mathrm{L}$ & 1.459 & 1.950 & 1.766 & 150 & 25 & 25 \\
\hline Cadmium, Cd & $\mathrm{mg} / \mathrm{L}$ & $<0.004^{(*)}$ & $<0.004^{(*)}$ & $<0.004^{(*)}$ & 0.9 & 0.15 & 0.15 \\
\hline Chromium, $\mathrm{Cr}$ & $\mathrm{mg} / \mathrm{L}$ & $<0.010^{(*)}$ & 0.093 & 0.014 & 15 & 2.5 & 2.5 \\
\hline Copper, $\mathrm{Cu}$ & $\mathrm{mg} / \mathrm{L}$ & 0.011 & 0.033 & 0.008 & 60 & 10 & 10 \\
\hline Mercury, Hg & $\mathrm{mg} / \mathrm{L}$ & $<0.001^{(*)}$ & $<0.001^{(*)}$ & $<0.001^{(*)}$ & 0.3 & 0.05 & 0.05 \\
\hline Lead, Pb & $\mathrm{mg} / \mathrm{L}$ & $<0.030^{(*)}$ & $<0.030^{(*)}$ & $<0.030^{(*)}$ & 3 & 0.5 & 0.5 \\
\hline Selenium, Se & $\mathrm{mg} / \mathrm{L}$ & $<0.002^{(*)}$ & $<0.002^{(*)}$ & $<0.002^{(*)}$ & 3 & 0.5 & 0.5 \\
\hline Zinc, Zn & $\mathrm{mg} / \mathrm{L}$ & 0.144 & 0.337 & 0.035 & 300 & 50 & 50 \\
\hline
\end{tabular}

${ }^{*}$ Method Detection Limit

Table 3: Metal Leaching Characteristics in WWTP Sludge of Dyeing-Finishing Textile Industry

\begin{tabular}{|c|c|c|c|c|c|c|c|c|c|c|}
\hline \multirow{2}{*}{ PARAMETER } & \multirow{2}{*}{ UNIT } & $\begin{array}{c}\text { Max } \\
\text { Standar }\end{array}$ & \multicolumn{8}{|c|}{ TCLP TEST RESULT } \\
\hline & & $\begin{array}{c}\text { before } \\
\text { Landfill }\end{array}$ & 2011 & 2012 & 2013 & 2014 & 2015 & 2016 & 2017 & 2018 \\
\hline Arsenic, As & $\mathrm{mg} / \mathrm{L}$ & 0.5 & $<0.003$ & $<0.003$ & $<0.003$ & $<0.003$ & $<0.003$ & $<0.003$ & $<0.003$ & $<0.003$ \\
\hline Silver, Ag & $\mathrm{mg} / \mathrm{L}$ & 5 & $<0.030$ & $<0.030$ & $<0.030$ & $<0.030$ & $<0.030$ & $<0.030$ & $<0.030$ & $<0.030$ \\
\hline Barium, Ba & $\mathrm{mg} / \mathrm{L}$ & 35 & 0.483 & 0.071 & 0.035 & $<0.030$ & 0.475 & 0.234 & $<0.030$ & $<0.030$ \\
\hline Nickel, Ni & $\mathrm{mg} / \mathrm{L}$ & 3.5 & 0.217 & 0.193 & 0.184 & 0.090 & 0.171 & 0.180 & 0.184 & 0.095 \\
\hline Cadmium,Cd & $\mathrm{mg} / \mathrm{L}$ & 0.15 & $<0.005$ & $<0.005$ & $<0.005$ & $<0.005$ & $<0.005$ & $<0.005$ & $<0.005$ & $<0.005$ \\
\hline Chrom,Cr(VI) & $\mathrm{mg} / \mathrm{L}$ & 2.5 & 0.005 & $<0.001$ & 0.003 & 0.004 & 0.005 & $<0.001$ & 0.003 & 0.004 \\
\hline Copper, Cu & $\mathrm{mg} / \mathrm{L}$ & 10.0 & 0.007 & $<0.005$ & $<0.005$ & 0.005 & 0.005 & $<0.005$ & $<0.005$ & $<0.005$ \\
\hline Mercury, $\mathrm{Hg}$ & $\mathrm{mg} / \mathrm{L}$ & 0.05 & $<0.001$ & $<0.001$ & $<0.001$ & $<0.001$ & $<0.001$ & $<0.001$ & $<0.001$ & $<0.001$ \\
\hline Lead, Pb & $\mathrm{mg} / \mathrm{L}$ & 0.5 & 0.330 & 0.243 & 0.119 & 0.135 & 0.330 & 0.103 & $<0.030$ & 0.179 \\
\hline Zinc, $\mathrm{Zn}$ & $\mathrm{mg} / \mathrm{L}$ & 50 & 0.151 & 0.047 & 0.035 & $<0.010$ & 0.151 & $<0.010$ & $<0.010$ & 0.033 \\
\hline
\end{tabular}




\subsection{Toxicity Characteristics Test of brick product}

Good combustion results in stable product. The existing metal content will burn to form oxides which are difficult to degrade naturally. Thus the properties as a Toxic and Hazardous material will decrease or disappear altogether. Another way to ensure that the brick products from textile waste are no longer toxic and hazardous, can be tested for acute toxicity.

Table 4 : TCLP Test Result

\begin{tabular}{|c|c|c|c|c|c|}
\hline \multirow{3}{*}{ Parameter } & \multirow{3}{*}{ Unit } & \multirow{3}{*}{$\begin{array}{c}\text { Test } \\
\text { Result }\end{array}$} & \multirow{2}{*}{\multicolumn{3}{|c|}{$\begin{array}{l}\text { Quality Hazardous Waste } \\
\text { Standard }\end{array}$}} \\
\hline & & & & & \\
\hline & & & TCLI & TCLP-E & $\begin{array}{l}\text { before } \\
\text { Landfill }\end{array}$ \\
\hline Arsenic, As & $\mathrm{mg} / \mathrm{L}$ & $<0.003$ & 3 & 0.5 & 0.5 \\
\hline Silver, Ag & $\mathrm{mg} / \mathrm{L}$ & $<0.030$ & 40 & 5 & 5 \\
\hline Boron, B & $\mathrm{mg} / \mathrm{L}$ & 0.745 & 150 & 25 & 25 \\
\hline Cadmium, $\mathrm{Cd}$ & $\mathrm{mg} / \mathrm{L}$ & $<0.004$ & 0.9 & 0.15 & 0.15 \\
\hline Chromium, $\mathrm{Cr}$ & $\mathrm{mg} / \mathrm{L}$ & $<0.010$ & 15 & 2.5 & 2.5 \\
\hline Copper, $\mathrm{Cu}$ & $\mathrm{mg} / \mathrm{L}$ & $<0.001$ & 60 & 10 & 10 \\
\hline Mercury, $\mathrm{Hg}$ & $\mathrm{mg} / \mathrm{L}$ & $<0.001$ & 0.3 & 0.05 & 0.05 \\
\hline Lead, $\mathrm{Pb}$ & $\mathrm{mg} / \mathrm{L}$ & $<0.030$ & 3 & 0.5 & 0.5 \\
\hline Selenium, Se & $\mathrm{mg} / \mathrm{L}$ & $<0.002$ & 3 & 0.5 & 0.5 \\
\hline Zinc, Zn & $\mathrm{mg} / \mathrm{L}$ & $<0.010$ & 300 & 50 & 50 \\
\hline
\end{tabular}

Table 5 : LD-50 Test Result

$\begin{array}{ll}\text { Sample Type } & : \text { Brick leachet extract } \\ \text { Test Animals } & : \\ \text { Type } & : \text { Swiss strain mice } \\ \text { Age } & : 6-8 \text { weeks } \\ \text { Sex } & : \text { Male \& Female } \\ \text { Weight Average } & : 27.65 \text { grams } \\ \text { Examination } & : \\ \text { Acclimatization } & : 1 \text { weeks } \\ \text { Exam. Time } & : 14 \text { days } \\ \text { Dose Amount } & : \text { oral, } 4 \text { treatment \& } 1 \text { control } \\ \text { Temperatur } & : 23 \pm 3{ }^{\circ} \mathrm{C} \\ \text { Humidity } & : 75 \pm 10 \%\end{array}$

LD-50 toxicity test result calculated based on the OECD Guideline 420 method are $>5000 \mathrm{mg} / \mathrm{kg}$ body weigt

According to table 4 Test Guideline Chapter IV Regulation of Head of the Republic Indonesia Drug and
Food Supervisor Agency No.7 year 2014, concerning Guidelines for Non-Clinical Toxicity Test in Vivo, stated that oral LD50 in mice 5 - 15 gram (1000 - $15000 \mathrm{mg}) /$ body weight, classified as practically non toxic - relatively harmless.

\subsection{Brick Quality Testing}

The next step is to test the mixture as a raw material for bricks, to ensure technical feasibility as a raw material for bricks. Preliminary tests include plasticity test and dry shrinkage test on mixed materials and bricks before burning. The test result are presented in tables 6 and tables 7 .

Table 6: Plasticity Test in Raw Material

\begin{tabular}{lcccc}
\hline \hline \multirow{2}{*}{ Parameters } & \multirow{3}{c}{ Units } & \multicolumn{3}{c}{ Composition } \\
& & V1 & V2 & V3 \\
\hline Liquid limit & $\%$ & 49.00 & 53.00 & 52.00 \\
Plastic Limit & $\%$ & 25.26 & 31.42 & 35.65 \\
Plasticity Index & $\%$ & 23.74 & 21.58 & 16.35 \\
\hline \hline
\end{tabular}

Note :

V1 : Composition with $0 \%$ sludge

V2 : Composition with $40 \%$ sludge

V3 : Composition with $60 \%$ sludge

Plastic is the character of a substance, allows the substance to change shape when externally acting on a force. The characteristic of plasticity in this case is very important to get an idea of the extent to which the material can be formed. This plasticity arises when clay is added with water while being resilient.

For bricks the good plasticity of the material ranges from $20-30 \%$. (R. Budi, 1995). Material with a plastic limit greater than $30 \%$ will produce many cracks during the drying process.

Table 7: Properties Test of Brick Material before Burning

\begin{tabular}{lcccc}
\hline \hline \multirow{2}{*}{ Parameters } & \multirow{3}{*}{ Units } & \multicolumn{3}{c}{ Composition } \\
& & V1 & V2 & V3 \\
\hline Dry Shrinkage & $\%$ & 7.55 & 6.76 & 6.46 \\
Max. Forming Water & $\%$ & 36.44 & 35.29 & 38.49 \\
Min. Forming Water & $\%$ & 28.56 & 26.72 & 33.70 \\
Flexural Strength & $\mathrm{kg} / \mathrm{cm}^{2}$ & 46.27 & 43.30 & 33.36 \\
\hline \hline
\end{tabular}




\section{Note :}

V1 : Composition with $0 \%$ sludge

V2 : Composition with $40 \%$ sludge

V3 : Composition with $60 \%$ sludge

The flexural strength is directly proportional to the plasticity index. The more mixed the waste, the smaller the flexural strength value and the smaller the plasticity index value. Based on empirical experiments that have been done by previous researchers, it shows that to get bricks that are goo's enough, the flexural strength must be above $28 \mathrm{~kg}$ /cm2 (R.Budi, 1995).

According to the flexural strength, the formulas V2, V3 qualify as raw material for bricks. The flexural strength value of raw materials reflects the compressive strength of brick products after burning(Author note: V1 was raw material, that no sludge to added)

Table 8: Physical Observations

\begin{tabular}{|c|c|c|c|c|c|}
\hline \multirow{2}{*}{ Code } & \multicolumn{5}{|c|}{ Parameters } \\
\hline & Size $(\mathrm{cm})$ & Form & Pores & Cracked & Color \\
\hline V1 & $23.1 \times 10.8 \times 4.5$ & Elbow & - & - & $\begin{array}{r}\text { reddish } \\
\text { brown }\end{array}$ \\
\hline V1 & $22.8 \times 10.7 \times 4.4$ & Elbow & + & + & $\begin{array}{r}\text { reddish } \\
\text { brown }\end{array}$ \\
\hline V2 & $23.1 \times 10.8 \times 4.5$ & Elbow & - & + & $\begin{array}{r}\text { reddish } \\
\text { brown }\end{array}$ \\
\hline V2 & $22.7 \times 10.9 \times 4.6$ & Elbow & - & - & $\begin{array}{r}\text { reddish } \\
\text { brown }\end{array}$ \\
\hline V3 & $22.7 \times 10.9 \times 4.6$ & Elbow & + & - & $\begin{array}{r}\text { reddish } \\
\text { brown }\end{array}$ \\
\hline V3 & $22.9 \times 11.1 \times 4.9$ & Elbow & + & ++ & $\begin{array}{l}\text { reddish } \\
\text { brown }\end{array}$ \\
\hline
\end{tabular}

\section{Note :}

V1 : Control bricks without sludge mixture

V2 : Bricks with a composition of $40 \%$ sludge

V3 : Bricks with $60 \%$ sludge

+ : enough / moderate

$+\quad$ : little

- $\quad$ : none

The physical observations of size, pores, cracks, and color, do not show a certain tendency to mix variations. Seen in control bricks that do not use a mixture of mud, pores and cracks are also found.

Possible causes are the nature of the material, the way it is cured or the drying process, so that it can be seen that the addition of $40 \%$ and $60 \%$ sludge as a mixture, has no real effect on physical observation. The raw material for bricks taken from dry land gives a different physical appearance to bricks that use raw materials from paddy soil. Dry soil has a harder texture and has larger grains, so it requires sufficient ductility to get a softer and more uniform mixture. In addition, withering must be done the brick are made, so that the mixture obtained is more compact.

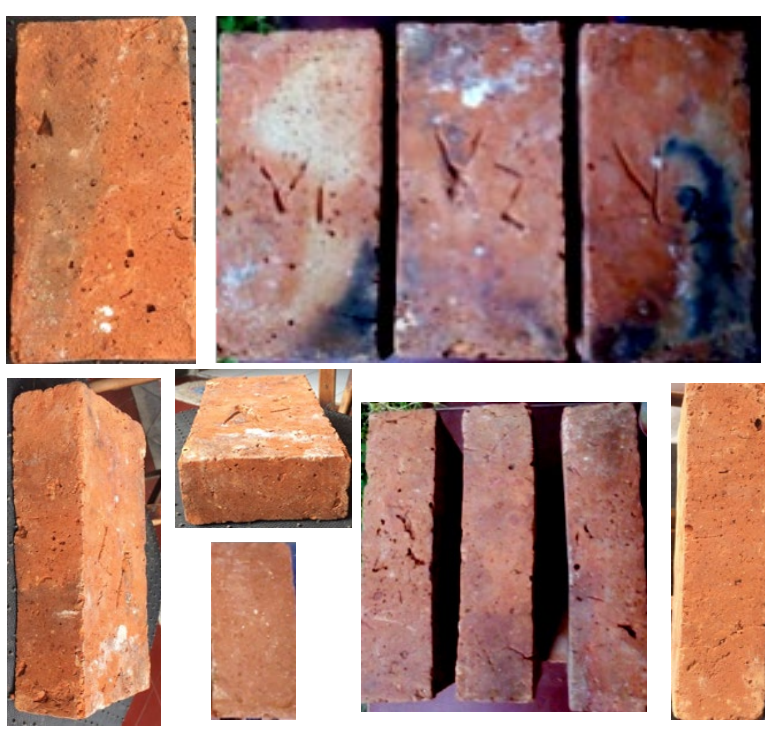

Figure 2: Physical images of Bricks

Table 9. Test Results of Bricks Products in Accordance with SNI

\begin{tabular}{|c|c|c|c|c|c|}
\hline \multirow{4}{*}{ No } & \multirow{4}{*}{ Code } & \multicolumn{4}{|c|}{ Testing Parameters } \\
\hline & & \multirow{3}{*}{ Size $(\mathrm{cm})$} & \multirow{3}{*}{ Form } & \multicolumn{2}{|c|}{ Absorp-Compressive } \\
\hline & & & & tion & Strength \\
\hline & & & & $(\%)$ & $\left(\mathrm{kg} / \mathrm{cm}^{2}\right)$ \\
\hline 1 & V2 & $23,13 \times 10,93$ & elbow & 25,25 & 203,294 \\
\hline 2 & V2 & $22,96 \times 10,83$ & elbow & 19,89 & 212,133 \\
\hline 3 & $\mathrm{~V} 2$ & $22,90 \times 10,80$ & elbow & 23,44 & 159,100 \\
\hline \multicolumn{2}{|c|}{ Average } & $\begin{array}{c}22,99 \times \\
10,85\end{array}$ & elbow & 22,86 & 191,509 \\
\hline \multicolumn{2}{|c|}{$\begin{array}{l}\text { Class } \\
\text { Standard } \\
100\end{array}$} & $\begin{array}{c}23 \pm 0,5 x \\
11 \pm 0,2\end{array}$ & elbow & 20 & $150 \pm 22,5$ \\
\hline 4 & V3 & $23,20 \times 11,1$ & elbow & 26,69 & 119,325 \\
\hline 5 & V3 & $22,53 \times 10,83$ & elbow & 28,51 & 163,519 \\
\hline 6 & $\mathrm{~V} 3$ & $22,70 \times 10,63$ & elbow & 29,07 & 150,261 \\
\hline \multicolumn{2}{|c|}{ Average } & $\begin{array}{c}22,81 \times \\
10,85\end{array}$ & elbow & 28,09 & 144,368 \\
\hline
\end{tabular}

Observation data and test results of brick laboratories using WWTP sludge as a mixture of making 
bricks raw material, show that the compressive strength and dimensions of brick products meet the quality requirements of National Indonesian Standard (SNI) Solid Brick for wall pairs with class 100 quality criteria.

\section{CONCLUSION}

Testing through TCLP (Toxicity Characteristic Leaching Procedure) test shows that the sludge used as a mixture of bricks meets the TCLP quality standard according to PP.110 of 2014 . The ideal composition of industrial wastewater sludge is $40 \%$ and $60 \%$. Testing of metal leaching with TCLP on brick products $40 \%$ and $60 \%$ of WWTP sludge, meets the TCLP Quality Standards according to PP 110 of 2014 . LD-50 acute toxicity test shows that bricks with a mixture of $60 \%$, obtained by the yield dose $>5000 \mathrm{mg} / \mathrm{kg}$ body weight, so it meets the allowable toxicity limit. Quality Test Results of Bricks using a mixture of WWTP sludge as much as $40 \%$ and $60 \%$ meet the requirements of National Indonesian Standard (SNI 15-2094-2000) solid red brick for wall pairs.

\section{REFERENCES}

Aeslina, 2014. An Overview of Sludge Utilization into Fired Clay Brick, World Academy of Science, Engineering and Technology International Journal of Environmental, Chemical, Ecologycal and Geographysical Engineering, Vol.8 No. 8 pp.557570

APHA, 2017. Standard Methods for The Examination of Water and Waste- water, $23^{\text {rd }}$ Ed. Part.3111.B

Balan, and Monteiro. 2001. Decolonization Of Textile Indigo Dye By Ligninolytic Fungi. J Biotechnol 89:141-145.

Peraturan Kepala Badan Pengawas Obat dan Makanan, Nomor 7 Tahun 2014, tentang Pedoman Uji Toksisitas Non Klinik Secara In Vivo, Badan Pengawas dan Obat dan Makanan Republik Indonesia

Kep.Ka. Bapedal No. Kep-03/Bapedal/09/ 1995 tentang Persyaratan Teknis Pengolahan Limbah Bahan
Beracun dan Berbahaya, Kementerian Lingkungan Hidup, Jakarta.

Baskar, K. M. Meera Sheriffa Begum, S. Sundaram. 2006. Characterizationand Reuse of Textile Effluent Treatment Plant Waste Sludge In Clay Bricks, Journal of the University of Chemical Technology and Metallurgy, vol. 41(4), pp. 473-478

Budi, R SK.1995.Studi Kekuatan Pasangan Batu Bata Pasca Pembakaran Menggunakan Bahan Additive Skripsi, Universitas Lampung, Bandar Lampung

BSN. 2000. SNI 15-2094-2000. Badan Standarisasi Nasional, ICS 91.100.20.

Eswaramoorthi S, Dhanapal K, Chauhan D. 2008. Advanced in textile waste water treatment: the case for UV-ozonation and membrane bioreactor for common effluent treatment plants in Tirupur, Tamil Nadu, India. Environment with People's Involvement \& Co-ordination in India, Coimbatore, India

Jahagirdar, S. 2013. Reuse of Textile Mill Sludge in Burnt Clay Brick. International Journal of Advanced Technology in Civil Engineering. Vo. 2 Issue-1, 96-98

Peraturan Pemerintah No. 101/2014 tentang Pengelolaan Limbah Bahan Berbahaya dan Beracun.

Method 1311 : (1992), Toxicity Characteristic Leaching Prosedure, Part of Test Methods for Evaluation Solid Waste, Physical/Chemical Methods, 33 pp $286 \mathrm{~K}$.

OECD Guidelines for The Testing of Chemicals. Section 4. 2002. Test N0 423: Acute toxicity- Acute Toxic Class Method. OECD Library

Powar, G. 2012. Farm Machinery and Power Textile, New Delhi : New India Publ. SAD ID40343169

Polprasert, C \& Liyanage. 1996. Hazardous Waste Generation and Processing, Elsievier Resources.

Yague, Yesaya, Gamalie dan Fatin F. 2002. Pembuatan Batu Bata dengan Lumpur Kering. Universitas Indonesia. Tidak dipublikasikan 